\title{
Characterization of mechanisms underlying degradation of sclerotia of Sclerotinia sclerotiorum by Aspergillus aculeatus Asp-4 using a combined qRT-PCR and proteomic approach
}

\author{
Xiaojia Hu ${ }^{1 \dagger}$, Lu Qin ${ }^{1 \dagger}$, Daniel P. Roberts ${ }^{2 *}$ (D, Dilip K. Lakshman², Yangmin Gong ${ }^{1}$, Jude E. Maul², Lihua Xie', \\ Changbing $\mathrm{Yu}^{1}$, Yinshui $\mathrm{Li}^{1}$, Lei Hu${ }^{1}$, Xiangsheng Liao ${ }^{1}$ and Xing Liao ${ }^{1 *}$
}

\begin{abstract}
Background: The biological control agent Aspergillus aculeatus Asp-4 colonizes and degrades sclerotia of Sclerotinia sclerotiorum resulting in reduced germination and disease caused by this important plant pathogen. Molecular mechanisms of mycoparasites underlying colonization, degradation, and reduction of germination of sclerotia of this and other important plant pathogens remain poorly understood.

Results: An RNA-Seq screen of Asp-4 growing on autoclaved, ground sclerotia of S. sclerotiorum for $48 \mathrm{~h}$ identified 997 up-regulated and 777 down-regulated genes relative to this mycoparasite growing on potato dextrose agar (PDA) for 48 h. qRT-PCR time course experiments characterized expression dynamics of select genes encoding enzymes functioning in degradation of sclerotial components and management of environmental conditions, including environmental stress. This analysis suggested co-temporal up-regulation of genes functioning in these two processes. Proteomic analysis of Asp-4 growing on this sclerotial material for $48 \mathrm{~h}$ identified 26 up-regulated and 6 down-regulated proteins relative to the PDA control. Certain proteins with increased abundance had putative functions in degradation of polymeric components of sclerotia and the mitigation of environmental stress.

Conclusions: Our results suggest co-temporal up-regulation of genes involved in degradation of sclerotial compounds and mitigation of environmental stress. This study furthers the analysis of mycoparasitism of sclerotial pathogens by providing the basis for molecular characterization of a previously uncharacterized mycoparasite-sclerotial interaction.
\end{abstract}

Keywords: Aspergillus, Gene expression, Mycoparasitism, Proteomics, Sclerotinia sclerotiorum

\section{Background}

Sclerotinia sclerotiorum (Lib.) de Bary is an important soilborne sclerotial pathogen that causes diseases on over 400 plant species from at least 75 families throughout the world including many major agronomic

\footnotetext{
*Correspondence: dan.roberts@ars.usda.gov; liaox@oilcrops.cn

${ }^{\dagger}$ Equal contributors

${ }^{2}$ Sustainable Agricultural Systems Laboratory, Henry A. Wallace Beltsville Agricultural Research Center, USDA-Agricultural Research Service, Beltsville, MD 20705-2350, USA

${ }^{1}$ Key Laboratory of Biology and Genetic Improvement of Oil Crops, Ministry of Agriculture, Oil Crops Research Institute, Chinese Academy of Agricultura Sciences, Wuhan 430062, People's Republic of China
}

crops [1, 2]. Application of fungicides is the primary method of disease control but control is problematic due to the residence of sclerotial resting structures in soil; these sclerotia being the source of initial inoculum for disease. Large amounts of fungicide are often required for soil pathogens and control can be inconsistent [3]. Loss of fungicide effectiveness due to the development of fungicide resistance in pathogen populations is also a concern [4-6]. Other disease control measures such as crop rotation can be ineffective due to the wide host range of $S$. sclerotiorum and the long persistence of recalcitrant sclerotial resting structures 
in soil [7]. Breeding for resistance has been hampered in some cases by a limited gene pool and the fact that resistance can be governed by multiple plant genes [8-10].

The use of mycoparasites as biological control agents is an alternative strategy for control of S. sclerotiorum $[3,11,12]$. These mycoparasites are applied to the field and expected to colonize and kill or weaken sclerotia resulting in the reduction of initial inoculum. Sclerotia, such as those produced by $S$. sclerotiorum, are hyphal aggregates that consist of a pigmented rind, a thin-walled cortex, and a large central medulla [13-15]. The cell walls of these hyphae consist primarily of glucan polymers; these glucans being predominantly $\beta-1,3$-linked polymers but $\beta-1,6-;$ mixed $\beta-1,3-$ and $\beta-1,4-; \alpha 1,3-;$ and $\alpha 1,4$-linked glucans have been found [16]. Chitin, a homopolymer of $\mathrm{B}$-1,4-linked $\mathrm{N}$-acetylglucosamine, is structurally important and can comprise as much as $10-20 \%$ of the cell wall. Additionally, fungal cell walls have glycoprotein, containing mannose and sometimes galactose moieties, interwoven within the chitin and glucan polymers [16]. Pigmentation in the sclerotial rind of S. sclerotiorum is due to melanin, in this case a polymer of dihydroxynapthalene [17]. In addition to the daunting physical barrier due to the complexity of these interwoven polymers, mycoparasites are likely to encounter potentially stressful conditions as $S$. sclerotiorum produces toxic phenolic compounds and fatty acids [18], reactive oxygen species [19], organic acids such as oxalic acid, and various enzymes capable of producing toxic products [20].

There has been some success in developing mycoparasites for production agriculture but grower acceptance of biological control products in general has been slowed by their inconsistent performance [21, 22]. For example, inconsistent performance has been reported in field trials with Coniothryium minitans in comparison with fungicide applications [4, 23]; C. minitans being the biological control agent in a commercial biological control product marketed for control of S. sclerotiorum. Molecular approaches have been used in recent years to more thoroughly understand the fungal - fungal interactions involved in mycoparasitic biological control strategies in attempts to improve their effectiveness; these molecular studies being largely limited to work with Trichoderma sp. and C. minitans [24-28]. Here we use transcriptomic, qRT-PCR, and proteomic approaches to characterize the mycoparasitic interaction between Aspergillus aculeatus isolate Asp-4 and sclerotia of S. sclerotiorum, expanding information regarding mycoparasitism of sclerotia with this study of an additional mycoparasitic fungal - sclerotia interaction. Isolate Asp-4 effectively inhibited germination of sclerotia of $S$. sclerotiorum in the field and reduced incidence of disease caused by this pathogen on oilseed rape $[29,30]$. Isolate Asp-4 was particularly effective in colonizing and degrading tissue of sclerotia of S. sclerotiorum, causing a $60 \%$ reduction in the mass of sclerotia over a $72 \mathrm{~h}$ period in vitro [30].

\section{Methods \\ Fungal isolate}

Aspergillus aculeatus isolate Asp-4 was obtained from the culture collection of the Plant Protection Laboratory, Oil Crops Research Institute, Wuhan, People's Republic of China where it was stored long-term in $20 \%$ glycerol at $-80{ }^{\circ} \mathrm{C}$. Isolate Asp- 4 was initially isolated from soil from a research plot at the Oil Crops Research Institute [31] and identified using morphological characteristics and sequence of ITS1 and ITS4 regions from rDNA. Unless indicated otherwise isolate Asp-4 was cultured in potato dextrose broth (PDB) or potato dextrose agar (PDA) plus $50 \mu \mathrm{g} / \mathrm{mL}$ hygromycin as this isolate was naturally resistant to that level of hygromycin. Isolate Asp-4 is also held in the Agricultural Culture Collection of China (Beijing) as ACCC 32502.

\section{RNA isolation from Asp-4, cDNA library preparation, and transcriptome sequencing}

RNA was isolated from Asp-4 grown on a medium containing sclerotia of $S$. sclerotiorum. For this medium sclerotia of $S$. sclerotiorum were collected from the field and verified through morphological examination and $18 \mathrm{~S}$ rDNA sequencing. DNA was extracted from sclerotia using standard procedures and the primers 18SrDNA-for (5' TCCGTAGGTGAACCTGCGG 3') and 18SrDNA-rev (5' TCCTCCGCTTATTGATATGC $\left.3^{\prime}\right)$ used to amplify $18 \mathrm{~S}$ DNA for sequencing [32]. Sclerotia verified as S. sclerotiorum were dried 3 days at 25 to $28^{\circ} \mathrm{C}$, ground with mortar and pestle, passed through a 20 mesh sieve, autoclaved at $121{ }^{\circ} \mathrm{C}$ for $30 \mathrm{~min}$ in $0.9 \% \mathrm{NaCl}$ in glass petri dishes, and autoclaved again at $121{ }^{\circ} \mathrm{C}$ for $30 \mathrm{~min}$. Petri dishes contained $5 \mathrm{~g}$ ground sclerotia in $15 \mathrm{~mL} 0.9 \% \mathrm{NaCl}$. Cellophane, containing $0.2 \mu \mathrm{m}$ holes (Cat. No. 11-40-0, Shanghai Biological Technology Co., Ltd., Shanghai) was autoclaved at $121{ }^{\circ} \mathrm{C}$ for $30 \mathrm{~min}$ in separate glass petri dishes and placed on top of the twiceautoclaved sclerotial material prior to inoculation with Asp-4. For the control, RNA was isolated from Asp-4 grown on sterile cellophane covering PDA.

For inoculation of these media, a $0.1 \mathrm{~mL}$ spore suspension of Asp-4 in $0.9 \% \mathrm{NaCl}\left(\geq 1 \times 10^{3}\right.$ spores/ $\left.\mathrm{mL}\right)$ from the $-80{ }^{\circ} \mathrm{C}$ freezer stock was placed on a PDA starter plate and incubated at $28{ }^{\circ} \mathrm{C}$. A $0.1 \mathrm{~mL}$ spore suspension of Asp- 4 in sterile $0.9 \% \mathrm{NaCl}\left(\geq 1 \times 10^{3}\right.$ spores/ mL) obtained from this starter plate was transferred onto the sterile cellophane covering ground sclerotia in glass petri dishes or covering PDA in the control. Mycelia of isolate Asp- 4 cultured for $48 \mathrm{~h}$ at $28{ }^{\circ} \mathrm{C}$ on five petri dishes containing crushed sclerotia were collected and combined 
and mycelia from Asp-4 cultured $48 \mathrm{~h}$ at $28{ }^{\circ} \mathrm{C}$ on five petri dishes containing the PDA control were collected and combined. Mycelia from both treatments were simultaneously snap-frozen in liquid $\mathrm{N}_{2}$ and stored at $-80{ }^{\circ} \mathrm{C}$ until used.

Mycelia in liquid $\mathrm{N}_{2}$ were ground with a mortar and pestle prior to RNA isolation with TRIZOL [33]. RNA quality was determined with a NanoPhotometer ${ }^{\circ}$ spectrophotometer (IMPLEN, Inc., Westlake Village, CA). Integrity and quantity of RNA was assessed using an RNA Nano 6000 Assay Kit with the Agilent Bioanalyzer 2100 system according to the manufacturer's instructions (Agilent Technologies, Santa Clara, CA). A total of $3 \mu \mathrm{g}$ high-quality RNA from each treatment was used for cDNA synthesis using the NEBNext ${ }^{\circ}$ Ultra $^{\text {Tm }}$ RNA Library Prep Kit for Illumina ${ }^{\circ}$ (New England Biolabs, Ipswich, MA) following the manufacturer's recommendations. Library quality was determined using the Agilent Bioanalyzer 2100 system. Clustering of the index-coded samples was performed on a cBot Cluster Generation System using the TruSeq PE Cluster Kit v3cBot-HS (Illumina, Inc., San Diego, CA) according to the manufacturer's instructions. After cluster generation, library preparations were sequenced on an Illumina HiSeq 2000 platform and paired-end reads generated.

\section{RNA-Seq transcriptome analysis, assembly, and functional} annotation

Raw data (raw reads) in fastq format were processed through in-house perl scripts to clean data by removing reads containing adapter, reads containing poly- $\mathrm{N}$, and reads of low quality. All downstream analyses were performed with the clean data. Q20, Q30, GC-content, and sequence duplication levels were calculated. Transcriptome assembly, based on left.fq and right.fq, was performed using Trinity (ver. 2012-10-05) [34] with min_kmer_cov set to 2 and all other parameters set to default. Gene function was annotated based on $\mathrm{Nr}$ (ver. 2014.1.25; National Center for Biotechnology Information [NCBI]), Nt (ver. 2014.1.25; NCBI), Pfam (ver. 27.0:2013.5.22), KOG/COG (ver. 2013:12.5), SwissProt (ver. 2014.1.25), KO (kaas_sa22; KEGG Ortholog), and GO (GO Blast2GO ver. 2.5; Gene Ontology) databases $[35,36]$. Gene Ontology enrichment analysis of the differentially expressed genes (DEGs) was conducted using the GOseq-R-package (GO Blast2GO ver. 2.5)-based Wallenius non-central hyper-geometric distribution [37]. KEGG pathway analysis was used to assign the allunigenes to biological pathways.

For the sequenced library, read counts were adjusted with the edgeR program package (ver. 3.0.8) [38] through one scaling normalized factor. Differential expression analysis was performed using the DEGseq $R$ package (ver. 1.10.1) [39]. Poisson distribution was used for $p$ value calculation and $p$ value was adjusted using $\mathrm{q}$ value [40]; q value $<0.005$, and $\log 2$ (fold change) $>1$ were used as the threshold for significant differential expression.

\section{Analysis of differential gene expression by qRT-PCR}

Genes were selected from the transcriptome data for analysis of differential expression by qRT-PCR. RNA was isolated using RNAiso (Takara, Shiga, Japan) from Asp-4 grown on crushed sclerotia or PDA as described above for various times and treated with RNAse-free DNase I (Thermo Fisher Scientific, Inc., Waltham, MA). First strand cDNA was synthesized from total RNA with an oligo(dT) 18 primer in a $20 \mu \mathrm{L}$ reaction using an M-MLV Reverse Transcriptase according to the manufacturer's instructions (Thermo Fisher Scientific, Inc., Waltham, MA). The synthesized cDNA was diluted and used as a template for real-time PCR reactions using a Real-Time PCR system (CFX Connect ${ }^{\mathrm{Tm}}$, Bio-Rad, Inc.). Each reaction $(20 \mu \mathrm{L})$ contained $10 \mu \mathrm{L}$ of Power $\mathrm{SYBR}^{\circ}$ Green PCR Master Mix (Applied Biosystems ${ }^{\circ}$, Foster City, CA), forward and reverse primers, cDNA template, and nuclease-free water. Primer Premier 5.0 (PREMIER Biosoft, Palo Alto, CA) was used for primer design (listed in Additional file 1: Table S1). PCR conditions were: $3 \mathrm{~min}$ at $95{ }^{\circ} \mathrm{C}(1 \mathrm{cycle}), 10 \mathrm{~s}$ at $95^{\circ} \mathrm{C}$ followed by $20 \mathrm{~s}$ at $55^{\circ} \mathrm{C}$ ( 45 cycles), and a melting curve ramping from 65 to $95{ }^{\circ} \mathrm{C}$ with an increasing temperature of $0.5{ }^{\circ} \mathrm{C}$. act and cox 5 transcripts, encoding actin and cytochrome $\mathrm{c}$ oxidase subunit $\mathrm{V}$, were used as internal references to normalize RNA in each reaction. Gene expression levels were calculated from the threshold cycle according to the $2^{-\Delta \Delta C T}$ method. All samples were analyzed in two independent experiments with three replicates.

\section{Protein extraction from Asp-4 mycelia for 2-D gel electrophoresis}

Mycelia of isolate Asp-4, cultured 48 h on crushed sclerotia or cultured $48 \mathrm{~h}$ on the PDA control, were collected separately, and snap-frozen in liquid $\mathrm{N}_{2}$ exactly as for the RNA transcriptome experiment. For the second experiment the same suspension of isolate Asp-4 that was used in the first experiment was transferred to the glass petri dishes containing sclerotia or the PDA control $16 \mathrm{~h}$ later. Frozen mycelia were ground in liquid $\mathrm{N}_{2}$ in a precooled mortar and pestle and extracted as per Hurkman and Tanaka [41] in Tris-saturated phenol and extraction buffer $(0.7 \mathrm{M}$ sucrose, $0.1 \mathrm{M} \mathrm{KCl}, 50 \mathrm{mM}$ EDTA, $0.5 \mathrm{M}$ Tris- $\mathrm{HCl}, \mathrm{pH} 7.5,2 \% \beta$-mercaptoethanol, and $1 \mathrm{mM}$ PMSF). The protein in the phenol phase was precipitated with $0.1 \mathrm{M}$ ammonium acetate in methanol followed by incubation at $-20{ }^{\circ} \mathrm{C}$ overnight. Precipitated protein was collected by centrifugation. The protein 
pellet was washed twice with pre-cooled methanol, twice with pre-cooled acetone, vacuum-dried, and stored at $-80{ }^{\circ} \mathrm{C}$ until used.

\section{Two-dimensional gel electrophoresis (2-DGE)}

Protein pellets were redissolved in rehydration buffer and protein concentrations determined with the Bradford assay [42]. Immobilized $\mathrm{pH}$ strips $(\mathrm{pH} 4-7$, nonlinear, $24 \mathrm{~cm}$, Immobiline Drystrip, BioRad, Hercules, CA) were rehydrated in protein solution for $12 \mathrm{~h}$ at $20{ }^{\circ} \mathrm{C}$ and isoelectric focusing (IEF) carried out using an Ettan IPGphor 3 isoelectric focusing system (GE Healthcare, Wauwatosa, WI) at $300 \mathrm{~V}(0.5 \mathrm{~h}$, step), $700 \mathrm{~V}(0.5 \mathrm{~h}$, step), $1500 \mathrm{~V}$ (1.5 h, step), $9000 \mathrm{~V}$ (3 h, gradient) and $9000 \mathrm{~V}$ (5 h, step) for a total of $64 \mathrm{kVh}$. Focused strips were equilibrated $15 \mathrm{~min}$ with equilibration buffer (100 mM DTT, $6 \mathrm{M}$ urea, 30\% $w / v$ glycerol, 2\% SDS, 50 mM Tris- $\mathrm{HCl}, \mathrm{pH} 8.8,0.002 \%$ bromophenol blue) and then for $15 \mathrm{~min}$ in the same equilibration buffer amended with $250 \mathrm{mM}$ iodoacetamide. The second dimension was performed in $12.5 \%$ sodium dodecylsulfate polyacrylamide gels (SDS-PAGE) on an Ettan DALTsix unit (GE Healthcare) according to the manufacturer's recommendations until the tracking dye reached the bottom of the gel. Gels were fixed and stained using Coomassie Brilliant Blue G (Sigma Chemical Co., St. Louis, MO) and silver stain. Stained gels were scanned and image analysis carried out with Image Master 2D Platinum 5.0 software (GE Healthcare). After scanning, individual protein spots were assigned a grey scale value. A protein in the sclerotia treatment was considered differentially expressed if its grey scale value was two-fold greater than or less than the corresponding protein in the PDA control treatment. Two replicate 2-DGE gels were run for each of the two experiments.

\section{In-gel digestion and protein identification by mass spectrometric analysis}

Differentially expressed protein spots were excised manually from the gels, destained, and digested with trypsin. After digestion, peptides were extracted with $60 \mu \mathrm{L}$ extract solution containing $2.5 \%$ trifluoroacetic acid and $90 \%$ acetonitrile, vacuum-dried, dissolved in $1.5 \mu \mathrm{L}$ matrix solution, and spotted onto a MALDI-TOF target plate. Mass spectrometric analysis of peptides from gel spots was performed using an Ultraflex III TOF/TOF mass spectrometer (Bruker Daltonics, Freemont, CA) using a UV laser with a wavelength of $355 \mathrm{~nm}$ and operated at a $200 \mathrm{~Hz}$ repetition rate. All acquired spectra of samples were identified using flexAnalysis (Bruker Daltonics), and the MS/MS data was analyzed using BioTools software (Bruker Daltonics) to search for proteins in the NCBI database with the following search parameters: protein molecular mass 800 to $4000 \mathrm{Da}$, MS tolerance set at $500 \mathrm{ppm}$, MS/MS tolerance of $0.5 \mathrm{Da}$.

\section{Validation of differential protein expression by qRT-PCR} Genes were inferred from the proteomic data for validation of differential expression by qRT-PCR. RNA preparation, primer design PCR cycling conditions, and analysis were as described for the qRT-PCR experiments. Primers used are listed in Additional file 2: Table S2. The same mycelia preparations used for the above protein extraction were also used for the RNA preparations. All samples were analyzed in at least two independent experiments with three replicates.

\section{Results}

RNA-seq transcriptome sequencing, sequence assembly, and functional annotation of Aspergillus aculeatus Asp-4 Transcriptomes of isolate Asp-4 grown on ground sclerotia of S. sclerotiorum in $0.9 \% \mathrm{NaCl}$ for $48 \mathrm{~h}$ at $28{ }^{\circ} \mathrm{C}$ and on the PDA control were determined from one experiment. Samples from each treatment produced over 2.3G raw data, had a Q20 of over 95\%, a Q30 of over $87 \%$, and a sequencing error rate lower than $0.05 \%$ indicating that the sequencing quality was suitable for further analysis. The samples were 56\% GC. Using the Trinity de novo assembly method, short sequence reads were assembled into 55,880 transcripts and these transcripts used for cluster and assembly analyses. A total of 37,278 unigenes were obtained of which 19,138 (51.34\%) were longer than $500 \mathrm{bp}$ (Additional file 3: Fig. S1a). All 37,278 unigenes were searched against $\mathrm{Nr}$, Nt, SwissProt, KEGG, and COG databases. These analyses revealed that 27,926 unigenes (74.91\%) had significant matches in the $\mathrm{Nr}$ database, 10,109 unigenes had significant matches in the $\mathrm{Nt}$ database (27.11\%), and 17,361 unigenes (46.57\%) had significant matches in the SwissProt database. Gene ontology (GO) assignments were used to classify the functions of Asp-4 unigenes in GO terms (Additional file 3: Fig. S1b). Greater than 10\% of unigenes in the biological process category were labeled with the terms biological regulation, cellular process, establishment of localization, localization, metabolic process, regulation of biological process, and response to stimulus. Greater than $10 \%$ of unigenes in the cell component category were labeled with the terms cell, cell part, macromolecular complex, membrane, membrane part, organelle, and organelle part. Finally, greater than $10 \%$ of unigenes in the molecular function category were labeled with the terms binding and catalytic activity. KEGG pathway tools were used to further identify biological pathways. The top 31 KEGG pathways are shown in Additional file 4: Fig. S2; with the largest percentage of unigenes $(>10 \%)$ classified under 
carbohydrate metabolism, amino acid metabolism, and translation. A large number of unigenes (5\% to $10 \%$ ) were also classified under transport and catabolism; signal transduction; folding, sorting, and degradation; energy metabolism; lipid metabolism; and metabolism of cofactors and vitamins.

\section{Transcriptional response of Aspergillus aculeatus Asp-4 during growth on sclerotia of $S$. sclerotiorum}

RNA-Seq data from Asp-4 grown on sclerotia of S. sclerotiorum for $48 \mathrm{~h}$ was compared with RNA-Seq data from Asp-4 grown on PDA for $48 \mathrm{~h}$ to screen for differentially expressed genes. A log2-fold difference in expression between treatments was used as the threshold. There were 997 genes up-regulated in the treatment where Asp-4 was grown on sclerotia as the nutrition source relative to Asp-4 grown on PDA and 777 genes down-regulated (Additional file 5: Tables S3 and Additional file 6: Table S4). Up-regulated genes included those from the following groups: carbohydrate metabolism, amino acid metabolism, energy metabolism, cell wall metabolism, regulation, heat shock protein, and transport. Down-regulated genes in the treatment where Asp-4 was grown on sclerotia as the nutrition source relative to Asp-4 grown on PDA included those involved in carbohydrate metabolism, amino acid metabolism, and transport.

A time course experiment was conducted using qRTPCR to determine changes in expression of 27 select Asp-4 genes, identified in the RNA-Seq screen experiment, over the initial $48 \mathrm{~h}$ of colonization of sclerotial material (Table 1). The experiment was performed twice. Mean values for expression from two experiments $(n=2)$ were only considered in the analysis when the mean was greater than the standard deviation of the mean.

Carbohydrate polymer degrading enzmes which potentially can degrade glycoprotein in fungal cell walls (mannan endo-1,4- $\beta$-mannosidase A, comp7543_c0) or which act on pectic material (pectin lyase F, comp10369_c0; endo- $\alpha-1,4$ polygalactoseaminidase, comp10792_c0; rhamnogalacturonate lyase A, comp15535_c0) and thus have been correlated with degradation of fungal cell walls [43, 44], were studied. Genes for all enzymes with the exception of pectin lyase A had levels of expression at $48 \mathrm{~h}$ that were greater than that at $12 \mathrm{~h}$ (Table 1 ). Notably, expression of mannan endo-1,4- $\beta$-mannosidase A was 630 -fold greater at $48 \mathrm{~h}$ than at $12 \mathrm{~h}$. Expression of the gene for endo-arabinase (comp15955_c0), another carbohydrate depolymerase, increased slightly from $12 \mathrm{~h}$ to $36 \mathrm{~h}$ and expression levels at $48 \mathrm{~h}$ were 150 -fold greater than at $12 \mathrm{~h}$ but highly variable (Table 1 ).

Expression of genes for three endoglucanases (Avicelase III, comp15820_c0; cell wall glucanase, comp10145_c0; endoglucanase-4, comp6428_c0), three 1,4- $\beta$-D-glucan cellobiohydrolases (A, comp13421_c0; B, comp17477_c0; C, comp19016_c0), and ß-glucosidase G (comp16375_c2) was also studied in the time course experiment (Table 1). A notable increase in expression of the endoglucanase Avicelase III was detected with expression at $48 \mathrm{~h}$ being 885 -fold greater than at $12 \mathrm{~h}$. There were also substantial increases in expression of cellobiohydrolase $\mathrm{A}$ and $\mathrm{C}$ genes and the $ß$-glucosidase $\mathrm{G}$ gene. Expression of all of these genes increased over the $48 \mathrm{~h}$ experiment. Lipids have been detected in sclerotia from S. sclerotiorum $[45,46]$. Genes associated with degradation of lipid were expressed during colonization of sclerotial material by Asp-4 as genes for lipase (comp10309_c0) and phospholipase (comp19032_c0) increased in expression over the $48 \mathrm{~h}$ experiment with levels of expression at $48 \mathrm{~h}$ being 20-fold and 4-fold greater, respectively, than those at $12 \mathrm{~h}$ (Table 1 ).

Expression of Asp-4 genes potentially involved in adapting to environmental stress conditions was also typically mani-fold greater at $48 \mathrm{~h}$ after initiation of colonization of the sclerotial material than at $12 \mathrm{~h}$ (Table 1). Notably, expression of the gene for heat shock trehalose synthase (comp13560_c0) was 3768fold greater at $48 \mathrm{~h}$ than at $12 \mathrm{~h}$ after initiation of colonization. Expression of the $30 \mathrm{kD}$ heat shock protein gene (comp17224_c0) was 15-fold greater at $48 \mathrm{~h}$ than at 12 h. Finally, a protease inhibitor (comp16974_c0) and oxylate decarboxylase (comp22183_c0) were 3-fold and 13 -fold greater, respectively, at $48 \mathrm{~h}$ than at $12 \mathrm{~h}$ after initiation of colonization. Expression of an $\mathrm{ABC}$ multidrug transporter (comp16806_c0) was also greater at $48 \mathrm{~h}$ than at $12 \mathrm{~h}$, with the level of expression 509-fold greater at $48 \mathrm{~h}$. These transporters transport compounds like toxic drugs and other compounds [47, 48]. Expression of a CDR ABC transporter (comp15840_c0) decreased from $12 \mathrm{~h}$ to $36 \mathrm{~h}$ and was too variable to be used in the analysis at $48 \mathrm{~h}$.

There was substantial up-regulation of four of the six transcription factors (RNA polymerase II transcription factor, comp7059_c0; fungal specific transcription factor domain protein, comp12975_c0; transcription factor TFIID complex $145 \mathrm{kDa}$ subunit, comp14528_c0; C6 transcription factor, comp15729_c0; GATA transcription factor LreB, comp16275_c7; transcriptional regulator Ngg1, comp15147_c0) studied and a sensor histidine kinase (sensor histidine kinase/response regulator, comp15130_c0) of Asp-4 during the initial $48 \mathrm{~h}$ of colonization of sclerotial material (Table 1). Expression at $48 \mathrm{~h}$ of all of these genes except RNA polymerase II transcription factor and transcriptional regulator Ngg1was at least 33-fold greater than at $12 \mathrm{~h}$, the greatest relative increase being 1936 -fold by the fungal specific transcription factor domain protein. Notably, 
Table 1 Relative expression values of genes during colonization of autoclaved sclerotia of Sclerotinia sclerotiorum by Aspergillus aculeatus Asp-4

\begin{tabular}{|c|c|c|c|c|c|}
\hline \multirow[t]{2}{*}{ Putative function } & \multirow[t]{2}{*}{ Gene ID } & \multicolumn{4}{|c|}{ Time after inoculation (Mean +/- SD) } \\
\hline & & $12 \mathrm{~h}$ & $24 \mathrm{~h}$ & $36 \mathrm{~h}$ & $48 \mathrm{~h}$ \\
\hline \multicolumn{6}{|l|}{ Glucanases } \\
\hline Avicelase III; [Aspergillus aculeatus] & Comp15820_c0 & $1.1 \pm 0.2$ & $5.1 \pm 1.2$ & $9.0 \pm 0.2$ & $885.0 \pm 122.0$ \\
\hline Cell wall glucanase; [Aspergillus niger CBS 513.88] & Comp10145_c0 & $1.1 \pm 0.1$ & $1.3 \pm 0.3$ & $1.3 \pm 0.2$ & $6.7 \pm 6.2$ \\
\hline Endoglucanase-4; [A. niger CBS 513.88] > gi|134,080,248 & Comp6428_c0 & $1.2 \pm 0.3$ & $(21.8 \pm 22.1)$ & $2.8 \pm 0.8$ & $(382.3 \pm 473.2)$ \\
\hline 1,4-ß-D-glucan cellobiohydrolase A & Comp13421_c0 & $0 \pm 0$ & $1.7 \pm 1.0$ & $0 \pm 0$ & $70.3 \pm 62.9$ \\
\hline 1,4-ß-D-glucan cellobiohydrolase B & Comp17477_c0 & $1.3 \pm 0.5$ & $(69.0 \pm 81.7)$ & $3.3 \pm 0.9$ & $(4173.7 \pm 4754.0)$ \\
\hline 1,4-ß-D-glucan cellobiohydrolase C; [A. niger CBS 513.88] & Comp19016_c0 & $1.0 \pm 0.1$ & $(146.1 \pm 157.3)$ & $25.6 \pm 15.8$ & $(64,056.3 \pm 87,096)$ \\
\hline B-glucosidase G [A. niger CBS 513.88] & Comp16375_c2 & $3.0 \pm 0.0$ & $3.66 \pm 0.0$ & $1.8 \pm 0.2$ & $48.2 \pm 29.2$ \\
\hline \multicolumn{6}{|l|}{ Other polysaccharide depolymerases } \\
\hline Mannan endo-1,4- $\beta$-mannosidase A & Comp7543_c0 & $1.9 \pm 1.2$ & $22.8 \pm 8.2$ & $16.0 \pm 2.7$ & $1167.2 \pm 642.8$ \\
\hline Pectin lyase F; [Aspergillus oryzae RIB40] > gi|391,874,352 & Comp10369_c0 & $11.7 \pm 1.3$ & $4.3 \pm 1.3$ & $1.6 \pm 0.8$ & $(33.1 \pm 35.1)$ \\
\hline Endo-a-1,4 polygalactosaminidase; [A. niger CBS513.88] & Comp10792_c0 & $4.1 \pm 0.6$ & $3.0 \pm 1.1$ & $1.2 \pm 0.3$ & $20.9 \pm 9.7$ \\
\hline Rhamnogalacturonate lyase A & Comp15535_c0 & $4.4 \pm 0.5$ & $3.0 \pm 1.1$ & $1.2 \pm 0.3$ & $20.0 \pm 10.9$ \\
\hline Endo-arabinase; [A. niger CBS 513.88] & Comp15955_c0 & $1.1 \pm 0.2$ & $3.4 \pm 0.2$ & $3.8 \pm 0.2$ & $154.6 \pm 153.0$ \\
\hline \multicolumn{6}{|l|}{ Lipases } \\
\hline Lipase; [A. niger CBS 513.88] > gi|134,083,043|e & Comp10309_c0 & $5.8 \pm 1.5$ & $6.3 \pm 0.8$ & $5.4 \pm 1.4$ & $120.2 \pm 94.6$ \\
\hline Phospholipase; [A. niger CBS 513.88] & Comp19032_c0 & $1.5 \pm 0.2$ & $1.6 \pm 0.4$ & $1.7 \pm 0.9$ & $6.0 \pm 1.9$ \\
\hline \multicolumn{6}{|l|}{ Environmental management } \\
\hline $\begin{array}{l}\text { Heat shock trehalose synthase; } \\
{[\text { A. niger CBS 513.88] > gi| } 134,084,204 \mid}\end{array}$ & Comp13560_c0 & $1.1 \pm 0.2$ & $11.1 \pm 3.6$ & $75.4 \pm 0.7$ & $4333.0 \pm 2354.2$ \\
\hline 30kD heat shock protein; [A. niger ATCC 1015] & Comp17224_c0 & $4.9 \pm 3.7$ & $3.3 \pm 3.3$ & $3.1 \pm 1.7$ & $73.3 \pm 36.7$ \\
\hline Protease inhibitor; [Talaromyces marneffei ATCC 1822] & Comp16974_c0 & $54.0 \pm 13.9$ & $10.5 \pm 4.6$ & $11.4 \pm 6.5$ & $165.2 \pm 94.7$ \\
\hline Oxylate decarboxylase OxdC; [Bacillus subtilis (strain 168)] & Comp22183_c0 & $1.0 \pm 0.0$ & $1.8 \pm 0.2$ & $5.5 \pm 0.2$ & $13.3 \pm 3.0$ \\
\hline CDR ABC transporter; [Byssochlamys nivea] & Comp16806_c0 & $20.6 \pm 6.9$ & $9.6 \pm 0.6$ & $4.4 \pm 1.5$ & $(166.4 \pm 175.2)$ \\
\hline ABC multidrug transporter; [A. oryzae RIB40] & Comp15840_c0 & $1.8 \pm 1.1$ & $692.6 \pm 203.7$ & $877.9 \pm 347.1$ & $915.9 \pm 83.8$ \\
\hline \multicolumn{6}{|l|}{ Regulation } \\
\hline $\begin{array}{l}\text { RNA polymerase II transcription factor } \\
{[\text { A. niger CBS 513.88] > gi|134,074,447| }}\end{array}$ & Comp7059_c0 & $1.2 \pm 0.3$ & $1.7 \pm 0.1$ & $2.7 \pm 1.5$ & $(346.1 \pm 354.4)$ \\
\hline $\begin{array}{l}\text { Fungal specific transcription factor domain protein } \\
\text { [A. niger CBS 513.88] }\end{array}$ & Comp12975_c0 & $1.8 \pm 1.1$ & $(10.6 \pm 12.2)$ & $10.0 \pm 6.4$ & $3428.3 \pm 3025.3$ \\
\hline $\begin{array}{l}\text { Transcription factor TFIID complex } 145 \text { kDa subunit } \\
\text { [Aspergillus kawachii IFO 4308] }\end{array}$ & Comp14528_c0 & $1.1 \pm 0.1$ & $1.6 \pm 0.3$ & $1.4 \pm 0.1$ & $49.8 \pm 32.6$ \\
\hline C6 transcription factor; [A. niger CBS 513.88] & Comp15729_c0 & $1.0 \pm 0.0$ & $1.3 \pm 0.3$ & $2.0 \pm 0.2$ & $87.3 \pm 74.4$ \\
\hline GATA transcription factor LreB; [Aspergillus fumigatus A1163] & Comp16275_c7 & $1.0 \pm 0.1$ & $2.8 \pm 0.0$ & $3.0 \pm 1.1$ & $35.1 \pm 23.1$ \\
\hline $\begin{array}{l}\text { Transcriptional regulator Ngg1; } \\
\text { [A. fumigatus Af293] > gi|66,847,840| }\end{array}$ & Comp15147_c0 & $1.7 \pm 0.5$ & $1.7 \pm 1.0$ & $3.6 \pm 0.9$ & $(124.0 \pm 127.3)$ \\
\hline Sensor histidine kinase; [Aspergillus clavatus NRRL & Comp15130_c0 & $1.2 \pm 0.2$ & $2.3 \pm 0.9$ & $2.8 \pm 0.0$ & $39.6 \pm 11.2$ \\
\hline
\end{tabular}

Gene expression levels were calculated from the threshold cycle according to the $2^{-\Delta \Delta C T}$ method. Values are the mean of two experiments $(n=2)$, each with three replicates, with standard deviation. act and cox 5 transcripts, encoding actin and cytochrome c oxidase subunit $\mathrm{V}$, were used as internal references to normalize RNA in each reaction. SD, standard deviation. Values in parentheses were considered too variable to be used in the analysis as the standard deviation was greater than the mean

expression of C6 transcription factor, which is associated with an oxidative stress response and the production of an anti-predation metabolite in Aspergillus spp. [49, 50], was 87 -fold greater at $48 \mathrm{~h}$ than at $12 \mathrm{~h}$. The expression of RNA polymerase II transcription factor and transcriptional regulator Ngg1 genes was fairly constant from $12 \mathrm{~h}$ to $36 \mathrm{~h}$ and too variable between experiments at $48 \mathrm{~h}$ to be used in the analysis. Transcriptional regulator Ngg1 is involved in glucose repression of Gal4pregulated genes [51]. 
Transcriptional response of Aspergillus aculeatus Asp-4 during growth on PDA

Two qRT-PCR time course experiments were also conducted to determine changes in expression of select Asp-4 genes over the initial $48 \mathrm{~h}$ of growth by this mycoparasite on PDA (Table 2). These experiments were conducted concurrently with the above time course experiments to determine if expression of genes on the sclerotial material was unique or possibly just due to growth on complex polymeric substrates. Mean values for expression were only considered in the analysis when the mean $(n=2)$ was greater than the standard deviation of the mean.

Almost all 27 Asp-4 genes analyzed by qRT-PCR that showed increased expression during growth on sclerotial material also showed increased expression during growth on PDA. The exceptions were 1,4-ß-D-glucan cellobiohydrolase A, where no expression was detected,

Table 2 Relative expression values of genes by Aspergillus aculeatus Asp-4 during growth on PDA

\begin{tabular}{|c|c|c|c|c|}
\hline \multirow[t]{2}{*}{ Putative function } & \multicolumn{4}{|c|}{ Time after inoculation (Mean +/- SD) } \\
\hline & $12 \mathrm{~h}$ & $24 \mathrm{~h}$ & $36 \mathrm{~h}$ & $48 \mathrm{~h}$ \\
\hline \multicolumn{5}{|l|}{ Glucanases } \\
\hline Avicelase III & $8.9 \pm 4.0$ & $(64.0 \pm 89.0)$ & $566.0 \pm 354.3$ & $(124.0 \pm 146.3)$ \\
\hline Cell wall glucanase & $1.9 \pm 0.0$ & $3.0 \pm 0.8$ & $6.7 \pm 0.8$ & $3.9 \pm 0.3$ \\
\hline Endoglucanase-4 & $1.9 \pm 0.3$ & $8.2 \pm 5.3$ & $71.0 \pm 12.8$ & $33.2 \pm 5.6$ \\
\hline 1,4-ß-D-glucan cellobiohydrolase A & $0.0 \pm 0.0$ & $0.0 \pm 0.0$ & $0.0 \pm 0.0$ & $0.0 \pm 0.0$ \\
\hline 1,4-ß-D-glucan cellobiohydrolase B & $2.6 \pm 0.2$ & $30.1 \pm 24.9$ & $212.7 \pm 159.5$ & $(128.6 \pm 149.4)$ \\
\hline 1,4-ß-D-glucan cellobiohydrolase C & $4.4 \pm 1.4$ & $(140.5 \pm 140.3)$ & $(2276.8 \pm 2527.7)$ & $286.9 \pm 148.4$ \\
\hline B-glucosidase G & $1.6 \pm 0.8$ & $5.4 \pm 2.9$ & $30.2 \pm 28.0$ & $14.3 \pm 3.8$ \\
\hline \multicolumn{5}{|l|}{ Other polysaccharide depolymerases } \\
\hline Mannan endo-1,4- $\beta$-mannosidase A & $48.9 \pm 19.1$ & $42.0 \pm 1.8$ & $145.2 \pm 98.7$ & $(36.1 \pm 36.1)$ \\
\hline Pectin lyase F & $6.1 \pm 4.1$ & $4.3 \pm 2.2$ & $(15.6 \pm 17.5)$ & $2.1 \pm 0.1$ \\
\hline Endo-a-1,4 polygalactosaminidase & $1.5 \pm 0.5$ & $3.3 \pm 1.0$ & $6.7 \pm 2.7$ & $2.9 \pm 0.0$ \\
\hline Rhamnogalacturonate lyase A & $1.5 \pm 0.5$ & $3.5 \pm 1.1$ & $5.7 \pm 2.0$ & $2.9 \pm 0.2$ \\
\hline Endo-arabinase & $2.0 \pm 0.4$ & $6.1 \pm 5.5$ & $99.8 \pm 87.5$ & $25.9 \pm 3.2$ \\
\hline \multicolumn{5}{|l|}{ Lipases } \\
\hline Lipase & $1.8 \pm 1.2$ & $13.9 \pm 4.9$ & $65.4 \pm 61.8$ & $17.8 \pm 1.8$ \\
\hline Phospholipase & $1.0 \pm 0.0$ & $2.1 \pm 1.3$ & $4.9 \pm 1.4$ & $5.2 \pm 1.0$ \\
\hline \multicolumn{5}{|l|}{ Environmental management } \\
\hline Heat shock trehalose synthase & $1.7 \pm 0.1$ & $50.0 \pm 40.9$ & $(931.1 \pm 1030.7)$ & $425.8 \pm 78.0$ \\
\hline 30kD heat shock protein & $9.3 \pm 1.7$ & $17.1 \pm 3.9$ & $92.9 \pm 1.7$ & $256.8 \pm 21.6$ \\
\hline Protease inhibitor & $10.5 \pm 1.7$ & $3.2 \pm 0.6$ & $9.2 \pm 1.7$ & $1.3 \pm 0.4$ \\
\hline Oxylate decarboxylase OxdC & $2.5 \pm 0.1$ & $13.2 \pm 0.0$ & $26.0 \pm 10.1$ & $12.9 \pm 2.8$ \\
\hline CDR ABC transporter & $1.1 \pm 0.2$ & $7.1 \pm 6.7$ & $(76.1 \pm 80.3)$ & $14.4 \pm 0.4$ \\
\hline ABC multidrug transporter & $2.0 \pm 0.5$ & $371.8 \pm 211.1$ & $1487.8 \pm 470.7$ & $9339.8 \pm 1873.5$ \\
\hline \multicolumn{5}{|l|}{ Regulation } \\
\hline RNA polymerase II transcription factor & $4.0 \pm 0.8$ & $26.1 \pm 8.4$ & $190.8 \pm 171.8$ & $61.3 \pm 7.6$ \\
\hline Fungal specific transcription factor domain protein & $1.7 \pm 0.2$ & $78.3 \pm 47.2$ & $(383.7 \pm 449.8)$ & $486.6 \pm 282.4$ \\
\hline Transcription factor TFIID complex $145 \mathrm{kDa}$ subunit & $1.8 \pm 0.5$ & $6.9 \pm 3.6$ & $15.1 \pm 11.5$ & $27.8 \pm 6.3$ \\
\hline C6 transcription factor & $2.2 \pm 0.4$ & $14.2 \pm 5.0$ & $52.6 \pm 44.0$ & $21.8 \pm 0.6$ \\
\hline GATA transcription factor LreB & $3.4 \pm 1.1$ & $7.0 \pm 5.1$ & $54.5 \pm 20.0$ & 43.20 .3 \\
\hline Transcriptional regulator Ngg1 & $2.8 \pm 1.0$ & $55.4 \pm 33.2$ & $199.8 \pm 104.4$ & $172.9 \pm 3.0$ \\
\hline Sensor histidine kinase & $6.4 \pm 0.2$ & $(6.3 \pm 6.2)$ & $68.3 \pm 50.9$ & $22.5 \pm 3.0$ \\
\hline
\end{tabular}

Gene expression levels were calculated from the threshold cycle according to the $2^{-\Delta \Delta C T}$ method. Values are the mean of two experiments $(n=2)$, each with three replicates, with standard deviation. act and $\operatorname{cox} 5$ transcripts, encoding actin and cytochrome $\mathrm{c}$ oxidase subunit $\mathrm{V}$, were used as internal references to normalize RNA in each reaction. SD, standard deviation. Values in parentheses were considered too variable to be used in the analysis as the standard deviation was greater than the mean. See Table 1 for the gene ID 
and pectin lyase $\mathrm{F}$ where expression declined over time during growth on both PDA and the sclerotial material (Tables 1 and 2). Expression of these genes tended to peak at $36 \mathrm{~h}$ during growth on PDA while expression of all genes was greatest at $48 \mathrm{~h}$ during growth on sclerotial material. The only genes that showed increased expression during growth on PDA that did not have peak levels of expression at $36 \mathrm{~h}$ were the $30 \mathrm{kDa}$ heat shock protein, $A B C$ multidrug transporter, fungal specific transcription factor domain protein, and transcription factor TFIID complex $145 \mathrm{kDA}$ subunit genes.

\section{Differential protein production by Aspergillus aculeatus Asp-4 during growth on sclerotia of S. sclerotiorum and on PDA}

In a parallel analysis, a comparison of proteomic profiles of Asp-4 grown on S. sclerotiorum sclerotial material for $48 \mathrm{~h}$ with that of Asp-4 grown on the PDA control was performed. Data generated from two experiments were used. There were 116 protein spots that exhibited differential accumulation between these two treatments; 93 proteins that were up-regulated in the treatment where Asp- 4 was grown on sclerotial material and 73 proteins that were down-regulated relative to growth on PDA (Fig. 1). MALDI TOF/TOF MS-MS analysis resulted in the identification of 33 proteins (Table 3). For the 26 identified up-regulated proteins, 18 were predicted to have different functions. Six of the down-regulated proteins were identified by MALDI TOF/TOF analysis (Table 4).

Twelve of these up-regulated proteins potentially played roles in degradation of sclerotial material and uptake of nutrients (Table 3). These included chitinase (spot \#B48, \#B49), aspartic protease (aspergillopepsin F; spot \# B60, \#B61, \#B62, \#B64), and lipase (spot \# 72, $\# 78$, \#80) which could target the chitin, glycoprotein, and lipid components of sclerotia, respectively. $\beta$-glucosidase (spot \#B27), $\alpha$-galactosidase (spot \# B06) and an outer membrane porin (spot \#B73) were also upregulated. $\beta$-glucosidases hydrolyze cellobiose and other short cello-oligosaccharides to glucose while $\alpha$ galactosidase hydrolyzes the terminal alpha-galactosyl moieties from glycolipids and glycoproteins. Porins play important roles in nutrient uptake and osmoregulation [52]. Notably, accumulation of the proteins B-glucosidase, the aspartic protease Aspergillopepsin F (spot \#B60, \#B61), lipase (spot \#B72), and the outer membrane porin (spot \#B73) by Asp-4 was unique to growth on sclerotial material; being completely absent during growth on PDA.

A second major function identified in up-regulated proteins was energy metabolism (Table 3). Two upregulated ATP synthase subunits (spot \#B32, \#B33), one ATPase subunit (spot \#B91), and two dihydrolipoamide

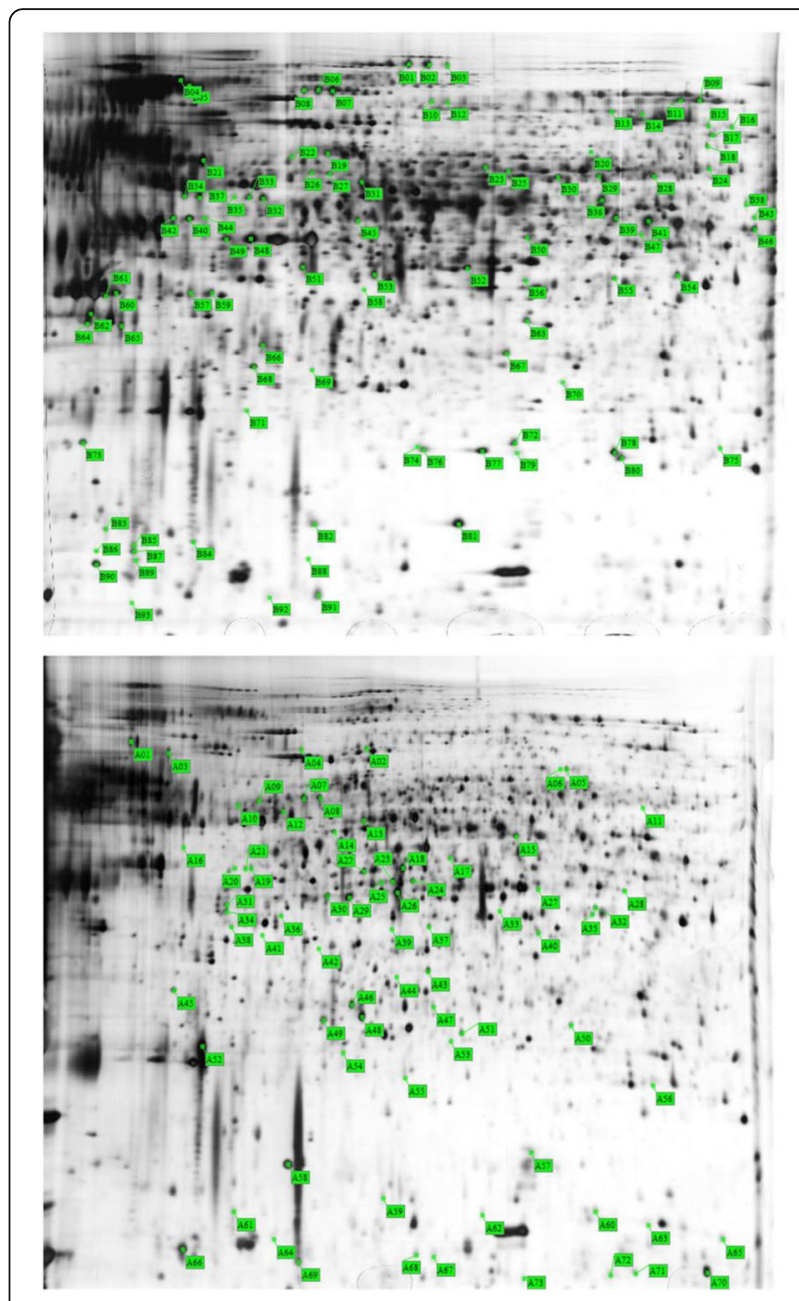

Fig. 1 2-D gel images of intracellular protein from Aspergillus aculeatus Asp-4. First dimension was carried out by IEF at pH 4-7. Second dimension was done in $12.5 \%$ SDS-PAGE. Numbered protein spots were differentially accumulated in mycelia of Asp-4 grown on sclerotia of Sclerotinia sclotiorum versus PDA and were processed for MALDI-TOF/TOF-MS-MS analysis and protein identification

dehydrogenases (spot \#B29, \#B30) were identified. Accumulation of one ATP synthase (spot \#B32) by Asp-4 was unique to growth on sclerotia. Accumulation of the ATP'ase (spot \#B91) was also unique to growth on sclerotia.

A third major group of up-regulated proteins contained predicted functions that could play roles in managing environmental stress (Table 3). These up-regulated proteins were predicted to be a catalase/peroxidase (spot \#B11), quinone-oxidoreductase (spot \#B52), dihydrobenzoic acid decarboxylase (spot \#B53), and a HAD superfamily hydrolase (spot \#B68). Accumulation of the catalase-oxidoreductase was unique to growth by Asp- 4 on sclerotial material. Catalase/peroxidases are bifunctional haem $b$-containing peroxidases with strong catalase activity and considerable peroxidase activity [53]. 
Table 3 Aspergillus aculeatus Asp-4 proteins up-regulated during colonization of Sclerotinia sclerotiorum sclerotial material identified with MALDI TOF/TOF MS

\begin{tabular}{|c|c|c|c|c|c|c|c|}
\hline Spot number & Accession number & Protein homology & $\begin{array}{l}\text { Molecular } \\
\text { mass }\end{array}$ & $\mathrm{pl}$ & Coverage & Score & Fold change \\
\hline B04 & GAQ44971 & Aspergillus niger vacuolar transporter chaperone 4. & 79.5 & 4.69 & 11 & 313 & 3.60897 \\
\hline B06 & Q9UUZ4 & A. niger a-galactosidase C; AltName: melibiase & 79.0 & 4.91 & 13 & 275 & 5.47248 \\
\hline B11 & KJJ35102 & Aspergillus catalase-peroxidase & 83.5 & 5.93 & 18 & 262 & 3.68319 \\
\hline B22 & KDE76293 & Aspergillus oryzae alpha tubulin & 50.1 & 4.94 & 25 & 171 & induced \\
\hline B26 & ACO35262 & Aspergillus clavatus tubulin B-chain & 50.0 & 4.85 & 18 & 212 & induced \\
\hline B27 & GAQ44092 & A. niger ß-glucosidase 1B & 54.4 & 5.22 & 30 & 260 & induced \\
\hline B29 & KMY30550 & Pseudomonas putida dihydrolipoamide dehydrogenase & 54.9 & 6.00 & 13 & 127 & 3.47691 \\
\hline B30 & DLDH2_PSEPU & Pseudomonas putida dihydrolipoamide dehydrogenase & 50.0 & 5.93 & 12 & 135 & 4.9281 \\
\hline B32 & WP047290153, KIR22521 & Pseudomonas fluorescens ATP synthase subunit beta & 49.4 & 4.92 & 37 & 203 & induced \\
\hline B33 & WP047290153, KIR22521 & P. fluorescens ATP synthase subunit beta & 49.4 & 4.92 & 37 & 230 & 15.6543 \\
\hline B48 & XP_750867.2 & Aspergillus kawachii class V chitinase C & 43.2 & 4.94 & 8 & 79 & 5.17274 \\
\hline B49 & GAA88849 & A. kawachii class $V$ chitinase & 43.2 & 4.94 & 19 & 62 & 8.23482 \\
\hline B50 & XP_001391510 & A. niger isovaleryl-CoA dehydrogenase 2 & 47.0 & 6.57 & 18 & 110 & induced \\
\hline B52 & Q95V68 & $\begin{array}{l}\text { Arabidopsis thaliana putative quinone-oxidoreductase } \\
\text { homolog }\end{array}$ & 35.8 & 5.66 & 22 & 155 & induced \\
\hline B53 & XP_001817513 & A.oryzae 2,3-dihydroxybenzoic acid decarboxylase & 39.0 & 5.32 & 16 & 210 & 6.14129 \\
\hline B60 & \multirow{4}{*}{$\begin{array}{l}\text { KEY77925, XP_753324, } \\
\text { EAL91286, AAB07619 }\end{array}$} & Aspergillus fumigatus aspergillopepsin F & 41.4 & 5.05 & 19 & 172 & induced \\
\hline B61 & & A. fumigatus aspergillopepsin $\mathrm{F}$ & 41.4 & 5.05 & 30 & 314 & induced \\
\hline B62 & & A. fumigatus aspergillopepsin $\mathrm{F}$ & 41.4 & 5.05 & 25 & 218 & 6.82982 \\
\hline B64 & & A. fumigatus aspergillopepsin $\mathrm{F}$ & 41.4 & 5.05 & 25 & 172 & 3.96381 \\
\hline B68 & GAA91284 & A. kawachii HAD superfamily hydrolase & 27.1 & 5.00 & 9 & 139 & 8.0873 \\
\hline B70 & GAA83245 & Aspergillus kawachii transcription initiation factor subunit & 26.1 & 5.64 & 17 & 74 & induced \\
\hline B72 & BAL22280 & Aspergillus niger lipase & 31.0 & 4.89 & 15 & 227 & induced \\
\hline B73 & WP_046722239 & Pseudomonas syringae outer membrane porin & 36.7 & 4.69 & 9 & 156 & induced \\
\hline B78 & BAL22280 & Aspergillus niger lipase & 31.0 & 4.89 & 17 & 256 & 47.6228 \\
\hline B80 & BAL22280 & Aspergillus niger lipase & 31.0 & 4.89 & 17 & 253 & 8.61288 \\
\hline B91 & XP_755466 & A. fumigatus V-type ATPase F subunit & 13.7 & 5.32 & 51 & 224 & induced \\
\hline
\end{tabular}

Six proteins were identified that accumulated in a potential ATP-dependent RNA helicase (spot \# greater quantity in hyphae of Asp-4 grown on PDA A14), and a potential spermidine synthase (spot than hyphae of Asp-4 grown on sclerotial material \#A43). All were not detected in hyphae of Asp-4 (Table 4). Notable protein spots were a potential grown on sclerotial material $(1,000,000$-fold less accuHSP70 Super Family heat shock protein (spot \#A02), mulation than on PDA). HSP70 proteins are stress

Table 4 Aspergillus aculeatus Asp-4 proteins down-regulated during colonization of Sclerotinia sclerotiorum sclerotial material identified with MALDI TOF/TOF MS

\begin{tabular}{llllllll}
\hline Spot number & $\begin{array}{l}\text { Accession } \\
\text { number }\end{array}$ & Protein homology & $\begin{array}{l}\text { Molecular } \\
\text { mass }\end{array}$ & pl & Coverage & Score & Fold change \\
\hline A02 & CBF80914.1 & Emericella nidulans 70 kDa Heat shock protein & 71.0 & 5.57 & 11 & 84 & Completely suppressed \\
A14 & GAQ46159 & Aspergillus niger ATP-dependent RNA helicase & 43.3 & 5.43 & 27 & 78 & Completely suppressed \\
A32 & GAQ43185 & A. niger class II aldolase/ adducin domain protein & 30.4 & 5.64 & 26 & 200 & Completely suppressed \\
A43 & XP_001268906 & spermidine synthase & 31.4 & 5.52 & 35 & 461 & Completely suppressed \\
A45 & GAA92032 & Aspergillus kawachii NADPH-dependent FMN reductase & 24.9 & 4.65 & 16 & 124 & 5.58 \\
A49 & GAQ44357 & A. niger peptidyl-prolyl cis-trans isomerase & 18.8 & 9.02 & 37 & 64 & Completely suppressed \\
\hline
\end{tabular}


response proteins expressed in the presence of biotic and abiotic stress [54-56].

\section{Validation of proteome results using qRT-PCR}

We analyzed via qRT-PCR 13 differentially expressed proteins (9 up-regulated proteins and 4 down-regulated proteins) to validate our quantitative data from the proteomic analysis (Table 5). Two of 4 proteins predicted to be down-regulated by proteomic analysis were up-regulated in the qRT-PCR analysis. The discrepancies were with the potential RNA helicase (spot \#A14) and the potential NADPH-dependent FMN reductase (spot \#A45). Eight of 9 proteins predicted to be upregulated by proteomic analysis were up-regulated in the qRTPCR analysis. The discrepancy was with the potential catalase-peroxidase (spot \#B11). In all, qRT-PCR analysis was in agreement with the proteomic analysis with regard to up- or down-regulation $77 \%$ of the time. Protein accumulation has been shown to vary from gene expression in certain instances $[57,58]$.

\section{Discussion}

This is the first study to our knowledge where transcriptomic, qRT-PCR, and proteomic approaches were used to study the mycoparasitic interaction between an Aspergillus sp. and sclerotia of S. sclerotiorum. As with other mycoparasites of S. sclerotiorum, Aspergillus aculeatus Asp-4 expressed a diverse collection of genes, or up-

Table 5 RT-PCR verification of up- and down-regulation of proteins

\begin{tabular}{llll}
\hline Spot & Putative function & \multicolumn{2}{l}{ Relative expression } \\
\cline { 3 - 4 } & & Sclerotia & PDA \\
\hline A14 & Translation initiation factor 4F & $3.18 \pm 0.10$ & $1.00 \pm 0.01$ \\
A43 & Spermidine synthase & $0.38 \pm 0.04$ & $1.00 \pm 0.10$ \\
A45 & NADPH-dependent FMN reductase & $8.98 \pm 0.08$ & $1.00 \pm 0.03$ \\
A49 & Peptidyl-prolyl cis-trans isomerase & $0.46 \pm 0.05$ & $1.00 \pm 0.05$ \\
B04 & Vacuolar transporter chaperone & $11.26 \pm 0.04$ & $1.00 \pm 0.36$ \\
B06 & a-Galactosidase & $8.17 \pm 0.01$ & $1.00 \pm 0.15$ \\
B11 & Catalase-peroxidase & $0.13 \pm 0.8$ & $1.00 \pm 0.07$ \\
B22 & Alpha tubulin & $1.46 \pm 0.06$ & $1.00 \pm 0.07$ \\
B26 & Tubulin beta chain & $40.70 \pm 0.09$ & $1.00 \pm 1.26$ \\
B27 & B-Glucosidase 1B & $120.50 \pm 0.06$ & $1.00 \pm 1.65$ \\
B52 & Quinone oxidoreductase & $2.61 \pm 0.06$ & $1.00 \pm 0.22$ \\
B53 & Dihydrobenzoic acid decarboxylase & $12.82 \pm 0.13$ & $1.00 \pm 0.33$ \\
B68 & HAD superfamily hydrolase & $20.00 \pm 0.06$ & $1.00 \pm 1.26$ \\
\hline
\end{tabular}

Gene expression levels were calculated from the threshold cycle according to the $2^{-\Delta \Delta C T}$ method with samples from Aspergillus aculeatus Asp- 4 grown on autoclaved, ground sclerotia of $S$. sclerotiorum and PDA. Values are the mean of two experiments $(n=2)$ each with three replicates per treatment with standard deviation. act and cox 5 transcripts, encoding actin and cytochrome $c$ oxidase subunit V, were used as internal references to normalize RNA in each reaction regulated enzymes, potentially functioning in the cleavage of the complex set of linkages within and between polysaccharide, glycoprotein, and lipid compounds comprising the sclerotium [24, 28]. It is readily apparent from molecular studies of these disparate mycoparasites that cooperative interaction between an assortment of enzymatic capabilities is needed to degrade the physical barrier posed by the interwoven mesh of polymers comprising sclerotia, allowing penetration by the mycoparasite and conversion of sclerotial components to nutrients. A. aculeatus Asp-4 up-regulated expression of genes for, or produced, chitinases, aspartic proteases (aspergillopepsin F), mannan endo-1,4- $\beta$-mannosidase A, $\alpha$-galactosidase, and lipases. Up-regulation of genes for, or production of these enzymes, has been detected in other mycoparasitic interactions [24, 44, 59]. Detection of genes or enzymes functioning in the degradation of sclerotial $\beta-1,3$ or $\beta-1,6$ glucan was notably absent from these analyses with Asp-4. However, culture filtrates from $A$. aculeatus Asp-4 growing on sclerotial material of $S$. sclerotiorum were shown to contain laminarinase activity in a prior study [30]. Laminarin is a linear $\beta-1,3$ glucan containing $\beta-1,6$ linkages. Expression of enzymes by Asp-4 capable of functioning in the degradation of melanin was also not detected during colonization of sclerotia.

It is interesting that Asp-4 up-regulated expression of genes for rhamnogalacturonate lyase $\mathrm{A}$, endo- $\alpha-1,4$ polygalactosaminidase, and endo-arabinase during colonization despite having no known substrate for these enzymes described within sclerotial material. Likewise, expression of genes for endoglucanases, 1,4- $\beta$-D-glucan cellobiohydrolases, and a $\beta$ glucosidase was detected during growth of Asp-4 on sclerotia. Expression of these $\beta$ 1,4-glucanases allows growth on $\beta$-1,4-glucan polymers but $\beta-1,4$-glucan polymers such as cellulose have not been found in cell walls of sclerotia. This was also the case for C. minitans during mycoparasitism of sclerotia of S. sclerotiorum [24]. ESTs with putative gene annotations of endo-1,4- $\beta$-xylanases and rhamnosidase A were detected despite xylan and rhamnose polymers having never been detected in sclerotia. Additionally, one or more $\beta-1,4$ glucanase, cellobiohydrolase, and $\beta$ glucosidase genes were expressed by $C$. minitans during growth on sclerotia of S. sclerotiorum [24]. It is possible that these carbohydrate depolymerases act as functional homologues to enzymes capable of degrading sclerotial compounds, that the appropriate corresponding polymers are present in sclerotia but have yet to be identified, or that they have the potential to function during saprophytic growth on plant residues and are co-regulated with enzymes that specifically target sclerotial components. Plant cell walls consist of polymers of rhamnose, galacturonic acid, arabinose, and xylose moities [60]. It 
should be noted that the cellophane used to cover the sclerotial material in petri dishes in our experiments reported here contained cellulose acetate suggesting that expression of 3 -1,4-glucanases may have been due, at least in part, to cellulosic compounds in the cellophane.

Another similarity with other mycoparasites of sclerotia of S. sclerotiorum $[24,61]$ was the co-regulation or coproduction of Asp-4 genes or proteins potentially functioning in adapting to environmental stress conditions with the production of these sclerotia-degrading enzymes. Genes for the heat shock proteins trehalose synthase and HSP30 were up-regulated with Asp-4 during the first $48 \mathrm{~h}$ of colonization of sclerotial material. Trehalose functions in thermal and oxidative stress protection $[62,63]$. The $30 \mathrm{kDa}$ heat shock protein HSP30 (AFU6G06470) plays a role in transcription regulation under heat shock conditions and higher expression of $\mathrm{Hsp} 30$ was observed both under heat stress and in response to $\mathrm{pH}$ stress [64]. A protease inhibitor gene was also up-regulated. Synthesis of protease inhibitors by the mycoparasite Aspergillus niger was postulated to be an adaptive stress response [65]. Additionally, Asp-4 up-regulated genes for, or produced, oxylate decarboxylase, quinone-oxidoreductase, dihydrobenzoic acid decarboxylase, and a HAD superfamily hydrolase; these enzymes potentially functioning in detoxification of compounds in the sclerotial environment. Disruption of an oxalate decarboxylase gene in C. minitans reduced the ability of this mycoparasite to infect $S$. sclerotiorum [61]. Oxalic acid is toxic to most organisms and degradation of oxalic acid by oxylate decarboxylase was thought to eliminate the toxic effect of this chemical and raise the $\mathrm{pH}$ making for a more beneficial environment for mycoparasitism [61, 66]. It has been postulated that reactive oxygen scavenging enzymes play key roles in oxidative and environmental stress responses in the mycoparasite C. minitans [24]. Several oxidoreductases, including quinone-oxidoreductase, were induced under osmotic shock of $T$. harzianum. They may counteract oxidative stress, provide NADPH for detoxification, or be involved in metabolism of oxidized molecules during metabolism [67]. Dihydrobenzoic acid has antifungal activity [68] and dihydrobenzoic acid decarboxylase may detoxify this compound. The HAD superfamily hydrolase has several functions including detoxification [69]. It should be noted that up-regulation of these genes/proteins was in response to growth on autoclaved material and not to an active response of the sclerotium to the presence of Asp-4.

The qRT PCR time course experiments with Asp-4 grown on sclerotial material and on PDA showed similarities in gene expression on these substrates (Tables 1 and 2). Almost all Asp-4 genes that showed increased expression during growth on sclerotial material also showed increased expression on PDA. The fact that both substrates contained complex mixtures of polymers including polysaccharides and proteins possibly explains this. However, the peak level of expression of genes during growth on sclerotial material tended to be at $48 \mathrm{~h}$ while the peak level of expression tended to be at $36 \mathrm{~h}$ on PDA. A possible explanation for this could be more rapid growth on PDA than the sclerotial material allowing the achievement of stationary phase more rapidly with concomitant earlier peak gene expression. PDA is a rich medium containing readily available nutrients such as dextrose in addition to mixtures of polymers while nutrients in the complex interwoven polymeric fabric of the sclerotial material may have been released more slowly. Genes for heat shock trehalose synthase, the $30 \mathrm{kDa}$ heat shock protein, and oxylate decarboxylase were also all up-regulated, although to different extents, during growth on PDA and on sclerotial material. This suggests that a portion of the Asp-4 environmental stress response was general in nature being activated by different environments/substrates.

\section{Conclusions}

In addition to substantiating parallels with other mycoparasitic interactions this study has provided the basis for molecular characterization of a previously uncharacterized mycoparasite-sclerotial interaction and may have identified previously uncharacterized genes and proteins functioning in mycoparasitism of sclerotia of S. sclerotiorum. Finally, the qPCR time course experiment comparing gene expression during growth of Asp-4 on sclerotial material with that of Asp-4 during growth on PDA indicates that care must be taken when interpreting transcriptomic or proteomic data where PDA was used as the control substrate. Growth on PDA resulted in upregulation of many genes shown to be up-regulated during growth on sclerotia of $S$. sclerotiorum.

\section{Additional files}

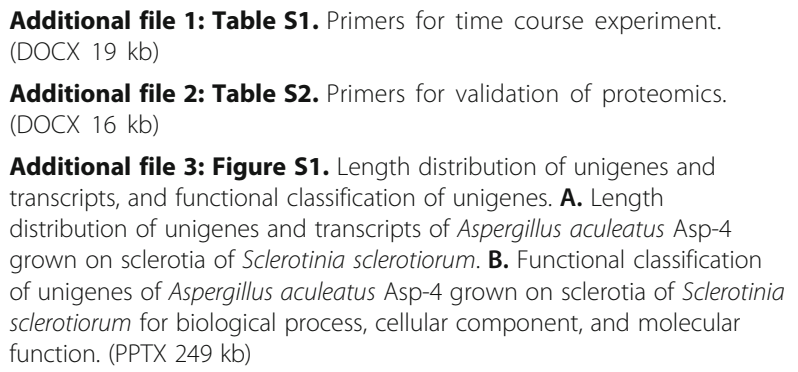

Additional file 2: Table S2. Primers for validation of proteomics. (DOCX $16 \mathrm{~kb}$ )

Additional file 3: Figure S1. Length distribution of unigenes and transcripts, and functional classification of unigenes. A. Length distribution of unigenes and transcripts of Aspergillus aculeatus Asp-4 grown on sclerotia of Sclerotinia sclerotiorum. B. Functional classification of unigenes of Aspergillus aculeatus Asp-4 grown on sclerotia of Sclerotinia sclerotiorum for biological process, cellular component, and molecular function. (PPTX $249 \mathrm{~kb}$ )

Additional file 4: Figure S2. KEGG classification of unigenes. KEGG classification of unigenes of Aspergillus aculeatus Asp-4 grown on sclerotia of Sclerotinia sclerotiorum. KEGG pathway grouping: A, cellular processes; $B$, environmental information processing; $C$, kinetic information processing; D, metabolism; E, organismal systems. (PPTX 369 kb)

Additional file 5: Table S3. Up-regulated genes vs CK. (XLS 738 kb) Additional file 6: Table S4. Down-regulated gene vs CK. (XLS 592 kb) 


\section{Abbreviations}

Asp-4: Aspergillus aculeatus Asp-4; PDA: Potato dextrose agar; PDB: Potato dextrose broth

\section{Acknowledgements}

The authors thank Laurie McKenna, USDA-ARS, Sustainable Agricultural Systems Laboratory, Beltsville, MD for help in data analysis.

\section{Funding}

This work was supported by grants from the Agricultural Science and Technology Innovation Program (contract number: CAAS-ASTIP-2013-OCRI), Special Fund for Agroscientific Research in the Public Interest (contract number: 201,503,123-09) and Excellent Young Scientist Fund of Chinese Academy of Agricultural Sciences (contract number: 1,610,172,015,004).

\section{Availability of data and materials}

Fungal cultures are available from the Agricultural Culture Collection of China.

\section{Authors' contributions}

$X H, X L, L Q$, and $D R$ designed the experiments; $X H, L X, L H, Y L, C Y, X L$, and LQ performed the experiments; $X H, L Q, Y G, D L, J M$, and DR analyzed the transcriptomic, $\mathrm{QRT}, \mathrm{PCR}$, and proteomic data; $\mathrm{DR}, \mathrm{XH}, \mathrm{LQ}$, and $\mathrm{XL}$ drafted the manuscript; and all authors read, helped revise, and approved the final manuscript.

\section{Ethics approval and consent to participate}

Not applicable.

\section{Consent for publication}

Not applicable.

\section{Competing interests}

The authors declare that they have no competing interests.

\section{Publisher's Note}

Springer Nature remains neutral with regard to jurisdictional claims in published maps and institutional affiliations.

\section{Received: 12 April 2017 Accepted: 4 August 2017}

Published online: 31 August 2017

\section{References}

1. Boland GJ, Hall R. Index of plant hosts of Sclerotinia sclerotiorum. Can J Plant Pathol. 1994;16:93-108.

2. Purdy LH. Sclerotinia sclerotiorum: history, diseases, symptom pathology, host range, geographic distribution, and impact. Phytopathology. 1979:69:875-80.

3. Clarkson J, Whipps J. Control of sclerotial pathogens in horticulture. Pest Outlk. 2002;13:97-101.

4. Fernando WGD, Nakkeeran S, Zhang Y, Savchuk S. Biological control of Sclerotinia sclerotiorum (lib.) de Bary by Pseudomonas and Bacillus species on canola petals. Crop Protect. 2007;26:100-7.

5. Yin Y, Liu X, Shi Z, Ma Z. A multiplex allele-specific PCR method for the detection of carbendazim-resistant Sclerotinia sclerotiorum. Pest Biochem Physiol. 2010;97:36-42

6. Wang Y, Duan Y, Wang J, Zhou M. A new point mutation in the iron-sulfur subunit of succinate dehydrogenase confers resistance to boscalid in Sclerotinia sclerotiorum. Mol Plant Pathol. 2015; doi:10.1111/mpp.12222.

7. Nelson B. Biology of Sclerotinia. Pages $1-5$ in: Proceedings of the $10^{\text {th }}$ International Sclerotinia Workshop, 21 January 1998, Fargo, North Dakota, USA. North Dakota State University Department of Plant Pathology, Fargo, N.D. 1998.

8. Bardin SD, Huang HC. Research on biology and control of Sclerotinia diseases in Canada. Can J Plant Pathol. 2001;23:88-98.

9. Fuller PA, Coyne DP, Steadman JR. Inheritance of resistance to white mold disease in a diallel cross of dry beans. Crop Sci. 1984;24:929-33.

10. Lu G. Engineering Sclerotinia sclerotiorum resistance in oilseed crops. Afr J Biotechnol. 2003;2:509-16.

11. Adams PB. The potential of mycoparasites for biological control of plant diseases. Annu Rev Phytopathol. 1990;28:59-72.
12. Zhou T, Boland GJ. Biological control strategies for Sclerotinia diseases. In: Boland CJ, Kuykendall LD, editors. Plant-microbe Interactioins and biological control. New York: Marcel Dekker; 1998. p. 127-56.

13. Jones D. Ultrastructure and composition of the cell walls of Sclerotinia sclerotiorum. Trans Brit Mycol Soc. 1970;54:351-60.

14. Colotelo N. A scanning electron microscope study of developing sclerotia of Sclerotinia sclerotiorum. Can J Bot. 1974;52:1127-30.

15. Kosasih BD, Willetts HJ. Ontogenetic and histochemical studies of the apothecium of Sclerotinia sclerotorum. Ann Bot. 1975;39:185-91.

16. Bowman SM, Free SJ. The structure and synthesis of the fungal cell wall. BioEssays. 2006;28:799-808.

17. Butler MJ, Bardiner RB, Day AD. Melanin synthesis by Sclerotinia sclerotiorum. Mycologia. 2009;101:296-304.

18. Pedras MS, Ahiahonu PW. Phytotoxin production and phytoalexin elicitation by the phytopathogenic fungus Sclerotinia sclerotiorum. J Chem Ecol. 2004;30:2163-79.

19. Georgiou DC, Tairis N, Sotiropoulou A. Hydroxyl radical scavengers inhibit sclerotial differentiation and growth in Sclerotinia sclerotiorum and Rhizoctonia solani. Mycol Res. 2000;104:1191-6.

20. Liang Y, Rahman MH, Strelkov SE, Kav NNV. Developmentally induced changes in the sclerotial proteome of Sclerotinia sclerotiorum. Fungal Biol. 2010;114:619-27.

21. Fravel DR. Commercialization and implementation of biocontrol. Annu Rev Phytopathol. 2005:43:337-59.

22. Glare T, Caradus J, Gelernter W, Jackson T, Keyhani N, Köhl J, Marrone P, Morin L, Stewart A. Have biopesticides come of age? Trends Biotechnol. 2012;30:250-8.

23. Huang HC, Bremer E, Hynes RK, Erickson RS. Foliar application of fungal biocontrol agents for the control of white mold of dry bean caused by Sclerotinia sclerotiorum. Biol Contrl. 2000:18:270-6.

24. Muthumeenakshi S, Sreenivasaprasad S, Rodgers CW, Challen MP, Whipps JM. Analysis of CDNA transcripts from Coniothyrium minitans reveals a diverse array of genes involved in key processes during sclerotial mycoparasitism. Fungal Genet Biol. 2007;44:1262-84.

25. Seidl V, Song L, Lindquist E, Gruber S, Koptchinskiy A, Zeilinger S, Schmoll M, Martínez P, Sun J, Grigoriev I, Herrera-Estrella A, Baker SE, Kubicek CP. Transcriptomic response of the mycoparasitic fungus Trichoderma atroviride to the presence of a fungal prey. BMC Genomics. 2009;10:567. doi:10.1186/ 1471-2164-10-567

26. Druzhinina IS, Seidl-Seiboth V, Herrera-Estrella A, Horwitz BA, Kenerley CM, Monte E, Mukherjee PK, Zeilinger S, Grigoriev IV, Kubicek CP. Trichoderma: the genomics of opportunistic success. Nat Rev. 2011;9:749-59.

27. Reithner B, Ibarra-Laclette E, Mach RL, Herrera-Estrella A. Identification of mycoparasitism-related genes in Trichoderma atroviride. Appl Environ Microbiol. 2011;77:4361-70.

28. Steindorff AS, Ramada MHSR, Coelho ASG, Miller RNG, Júnior GJP, Ulhoa JC, Noronha EF. Identification of mycoparasitism-related genes against the phytopathogen Sclerotinia sclerotiorum through transcriptome and expression profile analysis in Trichoderma harzianum. BMC Genomics. 2014;15:204.

29. Hu X, Webster G, Xie L, Yu C, Li Y, Liao X. A new mycoparasite, Aspergillus sp. ASP-4, parasitizes the sclerotia of Sclerotinia sclerotiorum. Crop Protect. 2013;54:15-22.

30. Hu X, Roberts DP, Xie L, Yu C, Li Y, Qin L, Hu L, Zhang Y, Liao X. Use of formulated Trichoderma Sp. Tri-1 in combination with reduced rates of chemical pesticide for control of Sclerotinia sclerotiorium on oilseed rape Crop Protect. 2016;79:124-7.

31. Hu X, Zhang MH, Yu CB, Xie L, Chen Y, Li Y, Liu S, Feng X, Zhang C, Liao X. Isolated fungal strains inhibiting sclerotial germination and their biocontrol properties. Chin J Oil Crop Sci. 2010;32:567-70.

32. Cao Y, Cheng P, Yu G, Li Y, Yang Z, Zhou L. Utility of universal primers, ITS1 and ITS4, to amplify sequences for race identification of Fusarium oxysporum f.Sp. cubense. Chin J Trop Crops. 2010;31:1098-102.

33. Chomczynski P, Sacchi N. Single step method of RNA isolation by acid guanidinium thiocyanate-phenol-chloroform extraction. Anal Biochem. 1987;162:156-9.

34. Grabherr MG, Haas BJ, Yassour M, Levin JZ, Thompson DA, Amit I, Adiconis X, Fan L, Raychowdhury R, Zeng Q, Chen Z, Mauceli E, Hacohen N, Gnirke A, Rhind N, di Palma F, Birren BW, Nusbaum C, Lindblad-Toh K, Friedman N, Regev A. Full-length transcriptome assembly from RNA-Seq data without a reference genome. Nat Biotechnol. 2011;29:644-52. 
35. Kanehisa M, Araki M, Goto S, Hattori M, Hirakawa M, Itoh M, Katayama T, Kawashima S, Okuda S, Tokimatsu T, Yamanishi Y. KEGG for linking genomes to life and the environment. Nucl Acids Res. 2008;36:D480-4.

36. Mao X, Cai T, Olyarchuk JG, Wei L. Automated genome annotation and pathway identification using the KEGG Orthology $(\mathrm{KO})$ as a controlled vocabulary. Bioinformatics. 2005;21:3787-93.

37. Young MD, Wakefield MJ, Smyth GK, Oshlack A. Gene ontology analysis for RNA-seq: accounting for selection bias. Genome Biol. 2010; doi:10.1186/gb2010-11-2-r14

38. Robinson MD, McCarthy DJ, Smyth GK. edgeR: a bioconductor package for differential expression analysis of digital gene expression data. Bioinformatics. 2010;26:139-40.

39. Wang L, Feng Z, Wang X, Wang X, Zhang X. DEGseq: an R package for identifying differentially expressed genes from RNA-seq data. Bioinformatics. 2010;26:136-8

40. Storey JD, Tibshirani R. Statistical significance for genomewide studies. Proc Natl Acad Sci U S A. 2003:100:9440-5.

41. Hurkman WJ, Tanaka CK. Solubilization of plant membrane proteins for analysis by two-dimensional gel electrophoresis. Plant Physiol. 1986;81:802-6.

42. Bradford MM. A rapid and sensitive method for the quantitation of microgram quantities of protein utilizing the principle of protein-dye binding. Anal Biochem. 1976;72:248-154.

43. Sukerbuyk MEG, Schaap PJ, Stam H, Musters W, Visser J. Cloning, sequence and expression of the gene coding for rhamnogalacturonase of Aspergillus aculeatus: a novel pectinolytic enzyme. Appl Microbiol Biotechnol. 1995;43:861-70

44. Vieira PM, Coelho AS, Steindorff AS, de Siqueira SJ, Silva RN, Ulhoa CJ. Identification of differentially expressed genes from Trichoderma harzianum during growth on cell wall of Fusarium solani as a tool for biotechnological application. BMC Genomics. 2013:14:177. doi: 10.1186/1471-2164-14-177 .

45. Sumner $\mathrm{J}$, Colotelo N. The fatty acid composition of sclerotia. Can J Microbiol. 1970;16:1171-8.

46. Colotelo N, Sumner JL, Voegelin WS. Chemical studies on the exudate and developing sclerotia of Sclerotinia sclerotiorum (lib.) DeBary. Can J Microbiol. 1971;17:1189-94.

47. Perlin MH, Andrews J, Toh SS. Essential letters in the fungal alphabet: $A B C$ and MFS transporters and their roles in survival and pathogenicity. Adv Genet. 2014;85:201-53.

48. Wang M, Sun X, Yu D, Xu J, Chung K, Li H. Genomic and transcriptomic analyses of the tangerine pathotype of Alternaria alternata in response to oxidative stress. Sci Rep. 2016;6:32437. PMID 27582273. doi:10.1038/ srep32437.

49. Yin W-B, Amaike S, Wohlbach DJ, Gasch AP, Chiang Y-M, Wang CCC, et al. An Aspergillus nidulans bZIP response pathway hardwired for defensive secondary metabolism operates through aflR. Mol Microbiol. 2012;83:1024-34.

50. Hong S, Roze LV, Linz JE. Oxidative stress-related transcription factors in the regulation of secondary metabolism. Toxins. 2013;5:683-702. doi:10.3390/ toxins5040683.

51. Brandl CJ, Furlanetto AM, Martens JA, Hamilton KS. Characterization of NGG1, a novel yeast gene required for glucose repression of GAL4pregulated transcription. EMBO J. 1993;12:5255-65.

52. Young MJ, Bay DC, Hausner G, Court DA. The evolutionary history of mitochondrial porins. BMC Evol Biol. 2007;7:31. doi:10.1186/1471-2148-7-31.

53. Welinder KG. Bacterial catalase-peroxidases are gene duplicated members of the plant peroxidase superfamily. Biochim Biophys Acta. 1991;1080:215-20.

54. Sanchez-Arreguin A, Perez-Martinez A, Herrera-Estrella A. Proteomic analysis of Trichoderma atroviride reveals independent roles for transcription factors BLR-1 and BLR-2 in light and darkness. Eukaryot Cell. 2012;11:30-41.

55. Kosawang C, Karlsson M, Jensen D, Dilokpimol A, Collinge D. Transcriptomic profiling to identify genes involved in Fusarium mycotoxin deoxynivalenol and zearalenone tolerance in the mycoparasitic fungus Clonostachys rosea BMC Genomics. 2014;15:55. doi:10.1186/1471-2164-15-55.

56. Montero-Barrientos M, Hermosa R, Nicolás C, Cardoza RE, Gutiérrez S. Monte E overexpression of a Trichoderma HSP70 gene increases fungal resistance to heat and other abiotic stresses. Fungal Genet Biol. 2008;45:1506-13.

57. Gygi SP, Rochon Y, Franza BR, Aebersold R. Correlation between protein and mRNA abundance in yeast. Mol Cell Biol. 1999;19:1720-30.

58. Tsai-Morris CH, Sheng Y, Lee E, Lei KJ, Dufau ML. Gonadotropin regulated testicular RNA helicase (GRTH/Ddx25) is essential for spermatid development and completion of spermatogenesis. PNAS USA. 2004;101:6373-8.
59. Sun Z-B, Sun M-H, Li S-D. Identification of mycoparasitism-related genes in Clonostachys rosea 67-1 active against Sclerotinia sclerotiorum. Sci Rep. 2015; 5:18169. doi:10.1038/srep18169.

60. Keegstra K. Plant cell walls. Plant Physiol. 2010;154:483-6.

61. Zeng LM, Zhang J, Han YC, Yang L, Wu MD, Jiang DH, et al. Degradation of oxalic acid by the mycoparasite Coniothyrium minitans plays an important role in interacting with Sclerotinia sclerotiorum. Environ Microbiol. 2014;16:2591-610.

62. Kandror O, DeLeon A, Goldberg AL. Trehalose synthesis is induced upon exposure of Escherichia coli to cold and is essential for viability at low temperatures. Proc Natl Acad Sci U S A. 2002;99:9727-32.

63. Gessler NN, Aver'yanov AA, Belozerskaya TA. Reactive oxygen species in regulation of fungal development. Biochemistry (Mosc). 2007;72:1091-109.

64. Tiwari S, Thakur R, Shankar J. Role of heat-shock proteins in cellular function and in the biology of fungi. Biotechnol Res Intl. Vol 2015, Article ID 132635 , p. 11 http://dx.doi.org/10.1155/2015/132635.

65. Vaseva I, Sabotič J, Šuštar-Vozlič J, Meglič V, Kidrič M, Demirevska K, et al. The response of plants to drought stress: the role of dehydrins, chaperones, proteases and protease inhibitors in maintaining cellular protein function. In: Neves DF, Sanz JD, editors. Droughts: new research. New York: Nova Science Publishers; 2012. p. 1-45.

66. Mäkelä MR, Hildén K, Lundell TK. Oxalate decarboxylase: biotechnological update and prevalence of the enzyme in filamentous fungi. Appl Microbiol Biotechnol. 2010;87:801-14.

67. DelgadoJarana J, Sousa S, González F, Rey M, Llobell A. ThHog1 controls the hyperosmotic stress response in Trichoderma harzianum. Microbiol. 2006;152:1687-700.

68. Benny PJ, George S, Kuriakose S, George C. 2,3-Dihydroxybenzoic acid: an effective antifungal agent isolated from Flacourtia inermis fruit. Int J Pharm Clin Res. 2010;2:101-5.

69. Koonin EV, Tatusov RL. Computer analysis of bacterial haloacid dehalogenases defines a large superfamily of hydrolases with diverse specificity. Application of an iterative approach to database search. J Mol Biol. 1994;244:125-32. doi:10.1006/jmbi.1994.1711.

\section{Submit your next manuscript to BioMed Central and we will help you at every step:}

- We accept pre-submission inquiries

- Our selector tool helps you to find the most relevant journal

- We provide round the clock customer support

- Convenient online submission

- Thorough peer review

- Inclusion in PubMed and all major indexing services

- Maximum visibility for your research

Submit your manuscript at www.biomedcentral.com/submit
Biomed Central 